\author{
Antonio Dos Reis \\ $\mathrm{PhD}$ in Education Sciences, Scientific coordinator, university teacher, consultant on e-learning \\ Director of the Graal Institute at the University of Extremadura, Spain \\ antoniodreis@gmail.com
}

\author{
Nataliia Morze \\ Sciences of Ukraine \\ Vice-Rector on Informational Technologies \\ Borys Grinchenko Kyiv University, Kyiv, Ukraine \\ n.morze@kubg.edu.ua \\ ORCID: 0000-0003-3477-9254 \\ Kateryna Osmolyk \\ Methodist of IT in Education Laboratory \\ Borys Grinchenko Kyiv University, Kyiv, Ukraine \\ k.osmolyk@kubg.edu.ua \\ ORCID: 0000-0002-1816-9299
}

Doctor of Pedagogical Sciences, Professor, Corresponding Member of National Academy of Pedagogical

\title{
HOW DOES OUR BRAIN CHANGE DURING THE LEARNING PROCESS
}

\begin{abstract}
This article is devoted to the brain changes during the leaning and teaching process. The results of the study present different tools and methods that equip modern educators and students. The author describes different aspects of the learning process and different learning styles. He provides some information about different stereotypes that appears on our way The author proposes the list of IT-competencies and methodological competences of teachers and students, necessary for been educator in the $21^{\text {st }}$ century. Is it really different to teach in the $21^{\text {st }}$ century than it was to teach in the $20^{\text {th }}$ century or before? Many people saying, that the great evolution was in technologies, but teaching - is teaching and nothing more than that. Our students are digital multi-modal learners, who have different learning styles. They learn quantities of information in a structured surface format they record in working memory and stored in permanent memory for interactivity and reflection. Nowadays students ask more and more multimedia contents. And this is the real profile of our clients, our students, they are asking this to us. Multimodal learning has versus multimedia teaching and humans are multimodal learners. They learn through words, written sentences, images, audio. And all of this shows that our brain has different areas for different functions. We should present our contents in different formats and this modifies format that we should offer our contents, gives us the opportunity to make simultaneous and synchronize. This means that information can be presented four times or more easy understanding of our students. When students use several communication channels it is like we are multiplying the information to be presented. This is the challenge of today. And this stimulates us to create a new pedagogical and technological methods which will be in tune with our time and which will help our students to use their brains operate at its full potential and for this we will need new educational strategies in today's digital environment
\end{abstract}

Keywords: e-learning; multimedia; behaviorist moment; constructivist moment; brain, challenges; didactical age; technologies; teaching process; learning process; learning styles; effectiveness

The purpose of the current article paper is to show how to learn in order to teach in the digital age. To encourage teachers for personal growth and to equip them in using ICT tools during learning and teaching process, in particular, to teach them how to present information in different formats, which increase the effectiveness of the learning and teaching process.

Is it possible to learn in order to teach in the digital age? What can we do to guide our students in the ocean of information and digital content in the digital age?

\section{Who are our students?}

Our students are digital learners and these students using variances means to collect information. They use not just reading and TV, but also they receive information through mobile phones and video games (Reis, 2008).

Our students are digital multi-modal learners, who have different learning styles. They learn quantities of information in a structured surface format they record in working memory 
and stored in permanent memory for interactivity and reflection. Nowadays students ask more and more multimedia contents (Reis, 2010).

And this is the real profile of our clients, our students, they are asking this to us.

Multimodal learning has versus multimedia teaching and humans are multimodal learners. They learn through words, written sentences, images, audio. And all of this shows that our brain has different areas for different functions. We should present our contents in different formats and this modify format that we should offer our contents, gives us the opportunity to make simultaneous and synchronize. This means that information can be presented four times or more easy understanding of our students (Cantu, Wilson, 2002). When students use several communication channels it is like we are multiplying the information to be presented.

Multimedia means (communication support) - Presenting concepts or processes, using images, narration and text messages.

\section{How does our brain change during learning and teaching process?}

We have three important moments: First, we receive information during the lesson, then we receiving information, our neurons are registering. After we go to stage two when we reflecting recording information. However, in stage 3 which is very important part of the structuring and organising information. It is when we are preparing presentations when we are discussing with our colleagues and so on (Stiles, 2006). Also, we can get information by multimodal communication and how does it work?

Since the XVIII century, several researchers are looking for the brain map.

Brodiman (1909) identify some specific areas for the perception of senses and emotions.

Only in the last decades, Antonio Damasio identifies the brain map and the multi-channel understanding process (Damasio, 1995). But what else, can we have about this?

We have to say that our brain changes. Depending on what is happening.

We are seeing like a video in front of us, up till a moment we have a click and then we start recording this information. And this information recording in short-term memory or working memory. This is behaviorist reaction and this is the first step of learning. After this step, we go to reflection and we go to the second step. In this step is really built your own technology. Now we are in the constructivist process now in long-term memory. But we have another step of constructivist process. So what else we have? When we are reflecting with our colleagues, or preparing works and so on. Now we are in the third stage. In this stage, we are organizing our memories. We are structuring what we memorize and record in our long-term memory.

This is the third stage of understanding!

And it is impossible to know how to teach and how to learn in the digital age, without to know how do we learn.

Is this applying to everyone in the same way? All humans equal, according to the behaviorism.

\section{There are three learning aspects of the learning process}

1. Memorizing and Understanding

2. Capturing information

3. Different learning styles

Let's return to learning styles. From Flaming VARK model, there are four profiles.

1. Visual

2. Aural

3. Read/Write

4. Kinesthetic (Fleming, 2002)

These are the four stereotypes that were identified by Flaming and it was as the VARK model.

But we have another perspective, according to Kob, Gardnner. 
We are:

1. Active

2. Reflective

3. Experimental

4. Theoretic

So this means that there is some contradiction, or it means that humankind has different perspectives, not four but maybe sixteen hybrid profiles. Let's reflect a little bit about it (Rosenberg, 2001).

In fact, we are more visual, aural, read/write, kinesthetic this is in the behaviorist moment

But if you are reflecting, we have different profile: we are actives, reflexives, experimental, theoretic and this is constructivism. This means that there are no effective contradictions in these two perspectives. In fact, they are in different moments of the learning process. Teachers should identify our students learning styles and prepare our contents presentations, according to their profile (Labour, 2000). As well we tutoring and formative assessment should be adjusted to the profile of our students. But learning styles are not homogenous and the changes can be done, along the life and according to the subject, we are studying (Rosie, 2000). And again this is very important it is

1. According to the life cycle

2. According to the moment of the learning cycle

3. According to the subject of studying

So about capturing information, it is an important moment. And about the importance of multi-channel communication (Downes, 2007). It means that according to several studies available from what we read, we cannot catch more than:

- $10 \%$ of what we read

- $20 \%$ of what we listen

- $20 \%$ of what we see

This means that first time a student attends to a presentation of one content, there is a barrier of $50 \%$ of the maximum of what he can get from that presentation, and this is in behaviourist moment (Anderson, 2001). But when we pass to constructivism moment we have another aspect to consider. Other aspects are, reflection is presenting, is debate with our mates and that can increase the receiving to about $100 \%$ of the contents to be presented (Reis, 2011). Intra persona.

The only missing thing is: Know how to learn and learn how to teach methods and techniques. These are both sides of the coin. Rules to be a good learner is important. The learner's work (McKenzie, 2000). Let us reflect on it

\section{8 rules to be a good learner:}

1. Stop thinking about other things while you are in class - relax

2. Focus on the presenter, slides, and materials

3. Pay attention to any non-verbal communication

4. Ignore other students, mobile phones and all other distraction factors

5. Take your notes

6. Write what you did not understand

7. Be mindful of selective attention

8. Think of and write 3 questions about each item

But more when we are in the constructivist moment. Which means transfer information from short-term memory to long-term memory and reflect about all these things, then you have another important step and in this important step are new rules. Because in the third stage you need to make reflection organize your memories with interactivity students to contents, interpersonal interactivity, student-to-student, student to teacher (Siemens, 2005). 
How do we understand and memorize? To increase knowledge and understand it is necessary (Cornelius, 2001). We reflect what we learn and there are different ways to do it: Reflection and. Interactivity can be from Student to contents, Intrapersonal, from Student to the student and from student to the teacher and formative assessment is very important for organizing and see if you are really receiving the information with quality (Masie, 2001).

Here 16 rules to be a good student in stage 2 from working memory to long-term memory

1. Organize the contents of topics

2. Be concentrated on the topic that you will study and ignore everything around you

3. Make a table of contents

4. Make a mental analysis recalling and describing the contents received

5. Do not underline topics underlined before, focus on other contents

6. Write a summary of each topic

7. Take notes about your doubts and clarify it with your teachers and colleagues

8. Try to understand a content in detail before doing exercises

Now we have another interesting and important moment. Which is debating and restructuring your memories this is the reflexive moment, on which you are organizing your memories and preparing yourself to learn more and more (Silva, 2000). This is the moment for you to reflect.

Rules at this moment are important too:

1. Write questions on each topic and discuss with your study group

2. Avoid transforming study group session into a live meeting

3. Present the contents to your mates or to yourself loudly (simulate being a teacher)

4. Avoid the big study marathons - start studying long before each exam

5. Do not believe you know everything only by knowing high-level concepts

6. Assess yourself and let yourself be assessed - formative assessment

7. Take 10 minutes' break for every $1 \mathrm{~h} 30$ studying

8. Sleep well and let your brain recover

Conclusions. About teachers' rules and teacher's work. Teachers should know as well how to guide our students. And for that, we need to make a couple of things.

Teacher's work prepares and presents the contents in multimodal and presenting that as a didactic communication tool, to help our students. Another aspect after, is what to do, to be
- Good tutor
- Guide
- Clarify doubts
- Promote debate

and make your student comfortable on reflecting and reorganizing their memories but as well promote formative assessment. It is very important to build memories. studying.

Because you can't control and our students can't control if they are making a good

Flipped classroom model is as well an interesting methodology to use in the digital age, for a successful study. And about conclusions we can say, as we have seen, we are receiving information in stage one, and we are as well recording information in stage two. We are reflecting structuring and organizing information in stage three. These are three important aspects in stages of the learning process. But more what else.

Learners and Teachers rules are important to make a very good interesting job on the learning process

I am prepared several studies: 
1. One about how to go from behaviourism to digital constructivism and all the changes associated with this.

2. Students profile evolutions and how does our brain changes during learning and teaching process

3. Disruptive innovation in education. Teaching models for the schools of the future with a focus on the "Flipped classroom model "

4. What are the teacher's skills to teach in the digital age?

Are you ready to be an e-missionary to teach in the digital age? If your answer Yes! When welcome who else if not you will change this world in the digital age?

And after reading this article who else if not you going to be a good teacher or even student who will be ahead of everyone in knowledge in this digital age.

\section{REFERENCES}

Anderson, L., W., \& Krathwohl. (2001). A Taxonomy for Learning, Teaching, and Assessing: A Revision of Bloom's Taxonomy of Educational Objectives. New York: Longman

Cornelius, S. (2001). Learning Online: Models and Styles. http://otis.scotcit.ac.uk/onlinebook/otis-t1.htm

Cantu, A. \& Warren, W. (2002). Teaching History in the Digital classroom. M. E. Sharpe, Inc. Armonk, NY, USA

Damasio, A. (1995) Descartes' error, emotion, reason and human brain, Publicações Europa America, Portugal Downes, S., 2005: E-Learning 2.0 http://www.downes.ca/post/31741

Downes, S. (2007). E-learning 2.0

http://www.elearnmag.org/subpage.cfm?section=articles\&article=29-1

Downes, S. (2007). Web 3.0 and Learning

http://www.downes.ca/cgibin/page.cgi?post $=36700$

Edwards, J. (2001). Multiple intelligences and theories

http://www.firn.edu/ face/about/dec95/mult_int.html

Fleming, N. (2002). VARK and active learning

http://www.activelearning-site.com/vark.htm

Gardner, H. (1983). Frames of mind: the theory of multiple intelligences. Basic Books.

Labour, M. (2000). Subject: "Learning styles" what's in a name Discussion Room: OTiS

- Tutor and Learner Styles, 4

http://otis.scotcit.ac.uk/e-book

Masie, E. (2001). An E-Learning Journey. In ROSENBERG, Marc J. - e-Learning: Strategies for Delivering Knowledge in lhe Digital Age. The Masie Cantar: McGraw-Hill.

McKenzie, J.(2000). Subject: none. Discussion Room: OTiS-Tutor and Learner Styles, 4 http://otis.scotcit.ac.uk/e-book

Reis A. (2011). Presentación conclusiones de la investigación y Ciclo de debates realizados sobre "Teacher's skills for the school of the future", International Scientific Conference "Theoretical and Practical Aspects in Distance Learning", University of Silesia in Katowice, Poland.

http://olcw.thegraal.net/TSSF/final_conclusions_uk.htm

Reis A. (2010). E-learning the Evolution In: Use of E-learning in the Training of Professionals in the Knowledge Society Monograph Sc. Ed. Smyrnova Trybulska, University of Silesia, Cieszyn, 13-32. ISBN 9788360071304

Reis A. (2009). Creative Learning Conference, "New skills for new jobs". http://olcw.thegraal.net/clc091016-01/clc091016.html

Reis A. (2010). About my experience as a teacher and trainer, Halmestad University Conference, Sweden. 
http://olcw.thegraal.net/diversos/1001halmestad/100126-Halmestad/100126- Halmestad.html Sweden.

Reis A. (2010). Implementing virtual classrooms. Uppsala University Conference,

http://uex.emea.acrobat.com/p53522716/

Reis A. (2008). New technologies and didactics in new methodologies environment. Innsbruck University press. ISBN: 9733902571670

Rosenberg, M. (2001). e-Learning: Strategies for Delivering Knowledge in the Digital Age. New York: McGraw-Hill. ISBN: 0-07-136268-1

Rosie, A. (2000). Subject: Many learning styles. Discussion Room: OTiS -Tutor and Learner Styles (4). 28 March 2001.

http://vls.scotcit.ac.uk/

Siemens, G. (2005). Connectivism: A Learning Theory for the Digital Age. http://www.elearnspace.org/Articles/connectivism.htm

Silva, A.J., Y. Elgersma, R. Costa. (2000). Molecular and cellular mechanisms of cognitive function: implications to psychiatric disorders. Biol Psychiatry, not published, (PDF)
Stiles
J. (2006).
Cognitive
brain
development.

http://www.youtube.com/watch?v=FugrcVhi2tg

\title{
ЯК ЗМІНЮЕТЬСЯ НАШ МОЗОК ПІД ЧАС НАВЧАЛЬНО-ВИХОВНОГО ПРОЦЕСУ
}

\author{
Морзе Наталія Вікторівна \\ Доктор педагогічних наук, професор, член-кореспондент НАПН України \\ Проректор з інформатизації навчально-наукової та управлінської діяльності \\ Київський університет імені Бориса Грінченка, м. Київ, Україна \\ n.morze@kubg.edu.ua \\ ORCID: 0000-0003-3477-9254
}

\begin{abstract}
Антоніо Дос Рейс
Доктор педагогічних наук, науковий координатор, викладач та консультант 3 дистанційного навчання, директор Інституту Грааля

Університет Естрамадура, Іспанія

antoniodreis@gmail.com
\end{abstract}

\section{Осмолик Катерина Олександрівна}

Методист Центру вебометрії та інформаційних систем

Науково-дослідної лабораторії інформатизації освіти

Київський університет імені Бориса Грінченка, м. Київ, Україна

k.osmolyk@kubg.edu.ua

ORCID: 0000-0002-1816-9299

Анотація. Дана стаття присвячена змінам мозку під час навчально-виховного процесу. Результати дослідження пропонують різні інструменти та методи, які оснащують сучасних педагогів та студентів. Автор описує різні аспекти навчального процесу та різні стилі навчання. Також він надає інформацію про різні стереотипи, які з'являються на нашому шляху. Автор пропонує перелік ІТ-компетенцій та методологічних компетенцій викладачів студентів, необхідних для вчителя та студента 21 століття. Чи справді процес навчання в 21му столітті, відрізняється від навчально-виховного процесу в 20-му столітті чи раніше? Багато людей вважають, що великих змін зазнали інформаційно-комунікаційні технології, але навчання - це навчання і нічого більшого. Наші студенти - це цифрові мультимодальні учні, які мають різні стилі навчання. Вони сприймають велику кількість інформації в структурованому поверхневому форматі і зберігають іiі в короткотривалій пам'яті. В довготривалій пам'яті учні зберігають інформацію для інтерактивності та рефлексії. Сьогодні студенти потребують все більше і більше мультимедійного змісту. Це профіль наших клієнтів, наших студентів, їх потреби і запит до нас. Мультимодальне навчання на противагу мультимедійному навчанню, в якому люди - мультимодальні учні. Вони навчаються через 
слова, написані тексти, зображення та аудіо. I все це показує, що наш мозок має різні області для різних функцій. Ми, як вчителі, маємо запропонувати зміст навчального матеріалу у різних форматах. Нові змінені формати, дають нам можливість одночасно синхронізувати учбовий матеріал в декількох форматах. Це означає, що інформація для наших студентів може бути представлена у чотири рази легшою для розуміння і запам'ятовування. Коли студенти використовують декілька комунікаційних каналів, це схоже на те, що ми множимо надану інформацію. І це наш виклик на сьогодні. Це стимулює нас до створення нових педагогічних і технологічних методів, які будуть в гармонії з сучасністю та допоможуть нашим учням використовувати свій мозок у повному обсязі і для цього нам необхідні нові освітні стратегії в сучасному цифровому середовищі.

Ключові слова: електронне навчання; мультимедіа; біхевіоризм; конструктивізм; мозок, проблеми; цифрова епоха; технології; навчальний процес; виховний процес; стилі навчання; ефективність 